\title{
EFFECT OF FOOD PROCESSING METHODS ON THE BIOACTIVE COMPOUND OF CAULIFLOWER
}

\author{
AFAF M. ALI \\ Horticultural Crops Processing Research Department, Food Technology Research \\ Institute, ARC, Giza, Egypt
}

(Manuscript received 25 November 2014)

\begin{abstract}
$\mathrm{B}$ rassica species are very rich in health-promoting phytochemicals, like phenolic compounds and vitamin C. The target of the present study was to determine the effect of different processing methods (boiling for $4 \mathrm{~min}$, boiling for $6 \mathrm{~min}$., steaming, microwaving for $2 \mathrm{~min}$, microwaving for $3 \mathrm{~min}$. and frying) on the nutrient components, phytochemical contents (vitamin C, TPC, TFC, total carotenoids) and antioxidant activity (DPPH) of white Cauliflower. Results showed that boiling process had a great negative effect on the nutrient components and caused significant losses of dry matter, protein, minerals and phytochemical contents. On the other hand, microwave showed the lowest reductions followed by frying and steam treatment. Methanol extract of fresh Cauliflower had the highest antioxidant activity (59.22\%) followed by the extracts of microwave ( 2 and $3 \mathrm{~min}$ ) and frying process $52.21 \%, 50.83 \%, 48.72 \%$, respectively. While steam and boiling (4 and 6 min.) Cauliflower recorded 42.49\%, $28.55 \%$ and 25.24\%, respectively.
\end{abstract}

\section{INTRODUCTION}

The Brassica vegetables (Broccoli, Cauliflower, Cabbage, Brussels sprouts) have been identified as an excellent source of antioxidants, not only because of the high levels present but also because they are vegetables that are regularly included in the diet, consumed in relatively large amounts and are available worldwide.

Subspecies of Brassica oleracea, including white and red cabbages (var. capitata), Broccoli and Cauliflower (var.bortrytis), savoy Cabbage (var. sabauda) and Brussels sprouts (var. gemmifera), belong to Cruciferous family (Brassicaceae). Brassica vegetables contain many bioactive compounds, especially organosulphur phytochemicals possessing anticarcinogenic activity and other phytochemicals, which are known to possess antioxidant activity. Dietary antioxidants present in these vegetables, such as water-soluble vitamin $\mathrm{C}$ and phenolic compounds, as well as lipidsoluble vitamin $E$ and carotenoids, contribute to both the first and the second defense lines against oxidative stress. As a result, they may protect humans from chronic diseases, such as cancer and cardiovascular disease. Among Brassica vegetables, kale, 
Brussels sprouts and broccoli are the most rich sources of antioxidant vitamins and carotenoids (Anwar et al. 2013).

In this aspect, the popularity and consumption of Brassica vegetables is increasing because of their nutritive value. The beneficial effects of Brassica vegetables on health improvement have been partly attributed to their complex mixture of phytochemicals possessing antioxidant activity, especially phenolic compounds and sulphur containing compounds, glucosinolates and their hydrolysis products. These sulphurous compounds are considered as indirect antioxidants, as they are not involved in the scavenging of free radicals directly, but rather by modulating the activity of xenobiotic metabolizing enzymes, phase I and phase II enzymes that trigger the antioxidant activity. Hence, an attempt has been made to review briefly the important compounds present in Brassicaceae with an emphasis on their biological activity as free radical scavengers (Savinder and Namita, 2013).

Cauliflower is an important vegetable grown all over the world and has a wide variety of uses directly as a vegetable or as an ingredient in salads, soups, and so forth. Cauliflower occupies an area of 8.88 million ha, having a production of 16.40 million tons in the world.

The content of natural antioxidants among Brassica vegetables varies significantly between and within their subspecies because of different maturity at harvest and conditions of growing, soil state and postharvest storage. Plant-derived products contain a wide range of phytochemicals, including antioxidants, which are thought to have a protective role against risk of oxidative stress-related diseases such as cancer and cardiovascular diseases. Therefore, a diet rich in vegetables and fruits and hence bioactive compounds, including natural antioxidants, has been associated with reduced risk of heart disease, cancer and diabetes.

Although fruits are mostly consumed in raw form, vegetables need to be cooked to enhance their palatability and taste. However, cooking brings about a number of physical and chemical changes in the vegetables. These changes could be both beneficial and detrimental depending on the extent and type of treatment conditions. Variety of effects like destruction, release and structural transformation of the phytochemicals take place during the cooking process. Cooking treatments like boiling, microwaving, baking, frying and griddling lead to changes in texture and nutritional properties of the vegetables. Studies had reported that cooking softens the cell walls which lead to increase in the extraction of carotenoids. However, other studies have reported that cooking can also lead to loss in essential vitamins and antioxidants, mostly water soluble and heat labile compounds. The extent of loss is 
dependent on the type of cooking treatment and the phytochemical compositions of the cooked vegetable (Sangeeta and Charu 2013).

Based on these facts, the present study was carried out to determine the effect of common domestic processes on the antioxidant activity of the phytochemicals of Cauliflower (Brassica oleracea Botrytis).

\section{Materials and Methods:}

2.1. Samples: Cauliflower (Brassica oleracea) samples were purchased from local markets in Giza Governorate, Egypt during the winter season (January 2014) and used as research materials. The inedible parts were removed using a sharp knife. The Cauliflower was cut into almost equal small bite-sized pieces (edible florets, about 5 $\mathrm{cm})$, mixed well, and divided into portions $(300 \mathrm{~g})$ then washed and dried at room temperature.

\subsection{Processing treatments:}

2.2.1. Boiling: Sample was placed into a stainless steel pan with $1000 \mathrm{ml}$. of boiling water $\left(100{ }^{\circ} \mathrm{C}\right)$ and covered with a lid. The boiling times were 4 or 6 minutes. The sample was drained off and cooled rapidly on plenty of ice.

2.2.2. Steaming: Sample was placed in a pressure cooker, containing water ( 1000 $\mathrm{mL}$ ) and a pressure valve for high pressure-cooking. The samples were drained off and cooled rapidly on plenty of ice.

2.2.3. Microwave: Sample was placed into a glass dish and $10 \mathrm{ml}$. of water was added. The dish was covered with cooking bag, having several holes and cooked in a Sharp Microwave Oven \{Model R-241R(S), $2450 \mathrm{MHz}$, Thailand\} on a high power level. The cooking times for each vegetable were 2 or $3 \mathrm{~min}$. The samples were drained off and cooled rapidly on plenty of ice. 2.2.4. Frying: Sample was placed in heated $\left(160 \pm 2{ }^{\circ} \mathrm{C}\right)$ sunflower oil $(100 \mathrm{~mL})$, and stirred until the sample became crisp-tender. At the end of each trial, sample was drained off and dabbed with blotting paper to allow for the absorption of exceeding oil.

\subsection{Analytical Methods:}

2.3.1. Chemical analysis: Moisture, protein, ether extract, ash, crude fiber, total carbohydrates (by difference), were determined according to A.O.A.C. (2005).

2.3.2. Minerals content: Potassium, Calcium, Magnesium, Phosphorous, Sulphur, Zink, Manganese and Iron contents were determined by using Perkin Elmer Atomic Absorption Spectrophotometer (3300) on described in A.O.A.C. (2005). The results are expressed as dry weight basis. 
2.3.3. Ascorbic Acid Determination: Ascorbic acid content was determined according to A.O.A.C. (2005) by 2, 6-dichloroindophenol titrimetric method. Ascorbic acid content is expressed as $\mathrm{mg} / 100 \mathrm{~g}$ dry weight.

2.3.4. Determination of Total Phenolic Contents (TPC): Total phenolic constituents of samples were performed employing the literature methods involving Folin- Ciocalteu reagent and gallic acid as standard (Slinkard and Singleton, 1977). Extract solution $(0.1 \mathrm{ml})$ containing $1000 \mathrm{mg}$ extract was taken in a volumetric flask, $46 \mathrm{ml}$ distilled water and $1 \mathrm{ml}$ Folin-Ciocalteu reagent were added and flask was shaken thoroughly. After $3 \mathrm{~min}, 3 \mathrm{ml}$ of solution $2 \% \mathrm{Na}_{2} \mathrm{CO}_{3}$ was added and the mixture was allowed to stand for $2 \mathrm{~h}$ with intermittent shaking. Absorbance was measured at $760 \mathrm{~nm}$. The same procedure was repeated to all standard gallic acid solutions.

2.3.5. Determination of Total Flavonoid contents (TFC): The total flavonoid contents was determined using the Dowd method (Brand et al., 1995). $5 \mathrm{~mL}$ of $2 \%$ aluminum trichloride ( $\mathrm{AICl} 3$ ) in methanol was mixed with the same volume of the methanol extract solution $(0.4 \mathrm{mg} / \mathrm{mL})$. After ten minutes the absorbance was measured at $415 \mathrm{~nm}$ using Perkin Elmer UV-VIS Lambda. Blank sample consisting of a $5 \mathrm{~mL}$ extract solution with $5 \mathrm{~mL}$ methanol without $\mathrm{AICl} 3$. The total flavonoid contents was determined using a standard curve with catechin $(0-100 \mathrm{mg} / \mathrm{L})$ as the standard. Total flavonoids content is expressed as $\mathrm{mg}$ of catechin equivalents (CE)/100 g dry weight.

2.3.6. Analysis of Phenolic Compounds Using HPLC: Fractionation and identification of phenolic compounds were determined by HPLC according to the method described by Goupy et al. (1999).

2.3.7. Total Carotenoids Determination: Total carotenoids were determined according to the procedure given by (Yuan et al., 2009), as follows: $5 \mathrm{~g}$ of samples were grinded and extracted with a mixture of acetone and petroleum ether $(1: 1, \mathrm{v} / \mathrm{v})$ repeatedly using the mortar and pestle until a colorless residue was obtained. The upper phase was collected and combined with crude extracts after being washed for several times with water. The extracts were made up to a known volume with petroleum ether. Total carotenoid contents was determined by recording the absorbance at $451 \mathrm{~nm}$ with a spectrophotometer. Total carotenoids were estimated by $\mathrm{mg} / 100 \mathrm{~g} \mathrm{DW}$.

2.3.8. Measurement of antioxidant activity by DPPH (2,2-diphenyl-1 picryl hydrazyl) radical scavenging method: The free radical scavenging capacity of samples extracts was noted through the change of optical density of DPPH radicals at $517 \mathrm{~nm}$ after $20 \mathrm{~min}$ incubation at room temperature. The total free radical 
scavenging capacity of the methanolic crude extracts was determined spectrophotometrically by measuring the disappearance of DPPH radical at an absorbance of $517 \mathrm{~nm}$. DPPH scavenging activity was calculated by using the equation:

$\%$ inhibition of DPPH $=\frac{\text { Abs control_Abs sample }}{\text { Abs control }} \times 100$

Where: Abs control is the absorbance of DPPH solution without extracts, Abs sample is the absorbance of DPPH with solution extracts (Ramesh and Satakopan 2010).

2.3.9. Statistical Analysis: All data were presented as means \pm standard deviation. Differences between variables were tested for significance by using ANOVA test, followed by multiple comparisons applied L.S.D (SAS 1986).

\section{Results and Discussion:}

3.1 Chemical composition: Table (1) showed that chemical composition of Cauliflower florets ( $\mathrm{g} / 100 \mathrm{~g}$ dry weight basis). The highest content of moisture was boiled sample for $6 \mathrm{~min}$. (92.37) followed by boiled at $4 \mathrm{~min} .(91.77)$ and steam (90.57). However microwave 2min. (90.15), microwave 3min. (89.89) and raw (86.23), respectively. While the lowest moisture content was fried sample was (85.73). Results revealed that boiling, steam and microwave caused significant increases in moisture content. This increase in moisture might be due to leaching of water-soluble nutrients during this process. However, was lower moisture contents than raw and other processing, during the frying process, water evaporates from inside the products being fried creating voids that are penetrated by the oil. Gernah et al., 2012 reported that frying process caused significant increase in fat content by $6.12 \%$ as dry weight basis. This might be due to absorption of oil through frying caused an increase of dry matter. While other processing caused significant decrease in fat content, these decrease were related to fat oxidation at high temperature or leaching effect. As for fiber contents it ranged from 10.07 to 10.23 in all treatments. Significant increase in fiber content was observed in boiling and steam process of Cauliflower. It could be attributed to the significant loss of dry matter into the boiling water. While most studies analyzing crude and dietary fiber reported no significant changes in crude or dietary fiber after canning and freezing. Fresh Cauliflower had significant the highest levels of ash $10.37 \%$ while cooking treatments were significantly $(P \leq 0.05)$ decrease the ash contents in Cauliflower florets. The highest reduction in the ash content was observed in boiling treatment. These result agree with (Souci et al., 1994) which reported loss of ash in boiled as compared with raw carrots. These decreases might be attributed to their diffusion into cooking water, while steam treatments microwaving and frying treatments gave the lowest reduction in the ash content. Losses of minerals during cooking are not caused by destruction 
but only by leaching into the cooking water. Fresh Cauliflower has significantly the higher level of protein $25.1 \%$. Boiling, steam, microwave and frying caused significant reductions in crude protein, these reductions were related to the protein denaturation at high temperature during blanching and cooking processes. It is possible that soluble proteins were lost by leaching to the surrounding water. The highest loss in protein content was observed for fried Cauliflower. This reduction was related to the fact that during the high temperature of frying, both protein and soluble sugar participated in Maillard reaction and then resulted in their content decline. The lowest loss was observed for Cauliflower (more than $1 \%$ ). Significant changes in carbohydrate content were observed after treatments of Cauliflower were observed. Moreover, a significant decrease in carbohydrate content was observed after frying of Cauliflower. This decrease may be attributed to the significant increase of fat content during frying process.

3.2. Minerals: Mineral contents of raw and cooked Cauliflower are shown in Table (2). Results showed that steam, microwaving, and frying treatments were the highest content of all minerals. On the other hand the greatest reduction in mineral contents were observed for boiled Cauliflower. These results are agreement with Puupponen et al., 2003 whose found that behavior of minerals during boiling is related to their solubility. The minerals leached from Cauliflower florets into the water during water boiling process. However, steam, microwaving, and frying treatments resulted in the greatest retention of all minerals. Steam is usually expected to conserve more soluble nutrients than boiling. Losses of minerals during cooking are not caused by destruction but only by leaching into the cooking water.

3.3 Ascorbic Acid: Table (3) show that the highest content of vitamin C was found in raw Cauliflower (63.4) followed by microwave at $2 \mathrm{~min}$. (54.730), microwave at 3min. (46.97). While, frying (43.4), boiling for 4 and $6 \mathrm{~min}$. (40.07 and $22.23 \mathrm{mg} /$ $100 \mathrm{~g}$ dry weight), respectively. Cooking treatments led to a significant deleterious on the vitamin C contents. Dramatic losses in the vitamin C contents in Cauliflower after boiling and microwave cooking were observed. These results are agreement with Shams El-Din, et al., (2013), they found that boiling for 6 minutes caused 64.93\% decrease in Cauliflower and they reported that boiling had a greater effect on vitamin C losses compared with microwaving, especially boiling for 6 minutes due to high solubility in water.

3.4 Total Phenolic Contents TPC: Also from Table (3), we noticed that the cooking treatments caused significant changes in the total phenolic contents in Cauliflower. The highest content of total phenolic contents was found in raw Cauliflower (762.9) followed by microwave for 2 and 3min. (632.3 and 619.9), 
respectively. While frying (612.8), boiling for 4 and 6min. were (364.2 and $542.2 \mathrm{mg}$ gallic acid/100g dry weight), respectively. Boiling was found to cause more significant changes than the microwave cooking. Sun and Zhuang, (2012) found that the short cooking time used in microwaving preserves the total phenolic contents of Cauliflower than the boiling. This could be due to the breakdown of phenolics or losses (leached out) during cooking as most of the bioactive compounds are relatively unstable to heat and easily solubilized.

3.5. Total Flavonoid Contents TFC: From the same Table, it is clear that the highest content of total flavonoids contents was found in raw Cauliflower (236.3) followed by microwave for 2 and 3min. (209.9 and 202.8), respectively. However, frying (198.0), boiling for 4 and 6min., (187.3 and $117.0 \mathrm{mg}$ Catechin $/ 100 \mathrm{~g}$ dry weight), respectively. It was observed that cooking caused a significant change in the vitamin C, phenolic and flavonoid contents in Cauliflower. Ismail, et al., (2004) reported that, Usually, thermal treatments have destructive effect on these components as they are highly unstable compounds .

3.6. Identification and quantification of phenolic compounds: The beneficial effects of Brassica vegetables on health improvement have been partly attributed to their complex mixture of phytochemicals possessing antioxidant activity. In recent years, considerable attention has been directed towards the identification of natural antioxidants, namely those plant derived that may be used for human consumption regarding health promotion and disease prevention. Phenolic compounds are characterized by having at least one aromatic ring with one or more hydroxyl groups attached. They can be classified based on the number and arrangement of their carbon atoms in flavonoids (flavonols, flavones, flavan-3-ols, anthocyanidins, flavanones, isoflavones and others) and non-flavonoids (phenolic acids, hydroxycinnamates, stilbenes and others) and they are commonly found conjugated to sugars and organic acids. The most widespread and diverse group of polyphenols in Brassica species are the flavonoids (mainly flavonols but also anthocyanins) and the hydroxycinnamic acids.

Table (4) presented 12 of phenolic compounds were identified and quantified in raw and processed Cauliflower. From Table (4) the predominant phenolics of raw Caulilower were alpa-cumaric (86.4), caffein (73.0), Vanillic (45.9), gallic (41.8), catechol (36.60), protocatchoic (32.50), reversterol (32.3), and p-coumaric (31.9) $\mathrm{mg} / 100 \mathrm{~g}$ edible portion, respectively. It could be noticed that processing affected negatively on the phenolic contents. The highest loss was observed for boiling Cauliflower, this could be due to the breakdown of phenolics or losses (leached out) during cooking as most of the bioactive compounds are relatively unstable to heat and 
easily solubilized. Lin and Harnly (2010) reveled that, generally, In Brassicaceae the most common hydroxycinnamic acids are p-coumaric, sinapic and ferulic acids, often found in conjugation with sugar and other hydroxycinnamic acids.

3.6. Identification and quantification of flavonoid compounds: Approximately 100 flavones have been identified in plants but they are less common in fruits and vegetables than flavonols. The most abundant flavones in plants are luteolin and apigenin. The flavonols, quercetin, kaempferol and isorhamnetin are among the flavonoid derivatives presnt in Brassica species (Chun et al., 2004). Table (5) presented 11 of flavonoid contents were identified and quantified in raw and processed Cauliflower. The predominant phenolics of raw Cauliflower were rutin (18.2), quercetin (16.6), naringinin (15.3), apegenin (14.60), kaempferol (13.9) and hisperdin (13.8 mg/100 g edible portion, respectively. It's clear that cooking of boiling Cauliflower caused further mostly reduction in phenolic acids and flavonoids contents in comparison to raw material. Polyphenols are well soluble in water and this is the reason of their big losses during cooking, in large amounts of water. These results agreement with (Sun and Zhuang 2012), they reported that boiling decreased the contents of these compounds of broccoli, while microwaving and steaming were better in retention of phenolic compounds than other treatments.

3.7.Total Carotenoids: Carotenoids are group of naturally occurring plant pigments that range in color from yellow to red, are well recognized for their antioxidant properties. Epidemiological evidence has shown that consumption of carotenoids from fruits and vegetables is protective against chronic diseases. From Table 6 and fig. 1 we noticed that the highest content was found in raw Cauliflower (132.11), followed by microwave for $2 \mathrm{~min} .(119.48)$, microwave for 3min. (114.67) and steam (108.27). While the low values were in boiling for $4 \mathrm{~min}$. (61.74) and frying (55.30), respectively. However, the lowest carotenoid contents was boiling for $6 \mathrm{~min}$. $(51.90 \mathrm{mg} / 100 \mathrm{~g}$ dry weight). Results of this study revealed that microwaving treatment resulted in higher carotenoid contents to that of boiling. Data in the Table 7 and fig. 1 also showed that boiling for 6 minutes declined the amount of carotenoid contents by $60.71 \%$ in Cauliflower. While microwaving for 2 and $3 \mathrm{~min}$. decrease carotenoid contents by 9.5 and $13.2 \%$, respectively. The high sensitivity of some carotenoids (like $\beta$-carotene) to light and heat is well recognized and its loss is therefore expected during heat processing. De Sa and Rodriguez (2004) noted also a reduction of carotenoids concentration in both boiled and stir-fried samples, the loss was as high as 22 and $4 \%$, respectively.

3.8. Total Antioxidant Activity: There are different methods for the estimation of antioxidant activity. DPPH radical is commonly used as substrate to evaluate 
antioxidant activity, it is a useful and stable free radical that can be accepted as electron or hydrogen radical to become a stable molecule. The results of scavenging DPPH radicals of studied raw and processed Cauliflower are summarized in the Table 6 and Fig.2. Higher \% Inhibition indicates better scavenging activity or antioxidant potential. There was decrease in antioxidant activity on boiling (51.8 to $57.4 \%$ inhibition) as compared to raw Cauliflower. It may be due to loss of vitamin C in the boiling Cauliflower. Also antioxidant activity decreased in both microwaving treatments ( 11.84 to $14.17 \%$ inhibition), frying (17.7\% inhibition) and steam (28.3\% inhibition) as compared to raw Cauliflower. The loss of antioxidant activity was relative to the contact area between vegetables and water as well as processing time. It was clear that the contact areas in microwave and frying processes were much smaller than that in boiling, so their antioxidant substances lost relatively small (Zhang et al., 2011). After boiling process, a lot of the antioxidant substances were running off into the boiling medium, which resulted in decrease of their antioxidant capacities. During vegetable cooking, qualitative changes, antioxidant breakdown, and their leaching into surrounding water may influence the antioxidant activity of the vegetables (Francisco et al., 2010).

Table 1. Effect of different processing methods on the chemical composition of Cauliflower florets ( $\mathrm{g} / 100 \mathrm{~g}$ dry weight basis).

\begin{tabular}{|c|c|c|c|c|c|c|c|c|}
\hline \multirow[b]{2}{*}{ Component } & \multirow[b]{2}{*}{ Raw } & \multicolumn{2}{|c|}{ Boiling } & \multirow[b]{2}{*}{ Steaming } & \multicolumn{2}{|c|}{ Microwave } & \multirow[b]{2}{*}{ Frying } & \multirow[b]{2}{*}{ L.S.D } \\
\hline & & $4 \mathrm{~min}$. & $6 \mathrm{~min}$. & & $2 \mathrm{~min}$. & $3 \mathrm{~min}$. & & \\
\hline Moisture & $\begin{array}{l}86.23 \mathrm{~b} \\
\pm 1.41\end{array}$ & $\begin{array}{l}91.77 \mathrm{a} \\
\pm 0.33\end{array}$ & $\begin{array}{l}92.37 \mathrm{a} \\
\pm 0.13\end{array}$ & $\begin{array}{l}90.57 \mathrm{a} \\
\pm 0.81\end{array}$ & $\begin{array}{l}90.15 \mathrm{a} \\
\pm 0.24\end{array}$ & $\begin{array}{l}89.89 \mathrm{~b} \\
\pm 0.22\end{array}$ & $\begin{array}{l}85.73 b \\
\pm 0.71\end{array}$ & 2.611 \\
\hline Ether extract & $\begin{array}{l}1.79 \mathrm{~b} \\
\pm 0.2 \\
\end{array}$ & $\begin{array}{l}1.62 \mathrm{c} \\
\pm 0.4 \\
\end{array}$ & $\begin{array}{l}1.60 \mathrm{c} \\
\pm 0.1\end{array}$ & $\begin{array}{l}1.58 \mathrm{~d} \\
\pm 0.4 \\
\end{array}$ & $\begin{array}{l}1.72 \mathrm{~b} \\
\pm 0.2 \\
\end{array}$ & $\begin{array}{l}1.75 \mathrm{~b} \\
\pm 0.4 \\
\end{array}$ & $\begin{array}{l}7.91 \mathrm{a} \\
\pm 0.3 \\
\end{array}$ & 0.258 \\
\hline Ash & $\begin{array}{l}10.37 \mathrm{a} \\
\pm 1.8 \\
\end{array}$ & $\begin{array}{c}9.77 \mathrm{~b} \\
\pm 0.2 \\
\end{array}$ & $\begin{array}{c}9.71 \mathrm{~b} \\
\pm 0.4 \\
\end{array}$ & $\begin{array}{l}9.73 \mathrm{~b} \\
\pm 0.2 \\
\end{array}$ & $\begin{array}{l}9.69 \mathrm{c} \\
\pm 0.4 \\
\end{array}$ & $\begin{array}{l}9.61 \mathrm{c} \\
\pm 0.2 \\
\end{array}$ & $\begin{array}{l}9.65 \mathrm{c} \\
\pm 0.3\end{array}$ & 0.691 \\
\hline protein & $\begin{array}{l}25.1 \mathrm{a} \\
\pm 1.3\end{array}$ & $\begin{array}{l}24.6 \mathrm{~b} \\
\pm 0.6\end{array}$ & $\begin{array}{l}24.3 b \\
\pm 0.4\end{array}$ & $\begin{array}{l}24.5 b \\
\pm 0.5\end{array}$ & $\begin{array}{l}24.0 \mathrm{c} \\
\pm 0.4\end{array}$ & $\begin{array}{l}24.8 b \\
\pm 0.7\end{array}$ & $\begin{array}{l}23.9 \mathrm{c} \\
\pm 0.8\end{array}$ & 0.644 \\
\hline fiber & $\begin{array}{l}10.23 \mathrm{a} \\
\pm 0.7 \\
\end{array}$ & $\begin{array}{l}10.10 \mathrm{~b} \\
\pm 0.4 \\
\end{array}$ & $\begin{array}{l}10.13 b \\
\pm 0.5\end{array}$ & $\begin{array}{l}10.07 \mathrm{c} \\
\pm 0.6\end{array}$ & $\begin{array}{l}10.11 \mathrm{~b} \\
\pm 0.3 \\
\end{array}$ & $\begin{array}{l}10.15 \mathrm{~b} \\
\pm 0.4\end{array}$ & $\begin{array}{l}10.20 \mathrm{a} \\
\pm 0.5 \\
\end{array}$ & 0.436 \\
\hline Carbohydrates & $\begin{array}{l}52.51 \mathrm{c} \\
\pm 0.5\end{array}$ & $\begin{array}{l}53.91 b \\
\pm 0.2\end{array}$ & $\begin{array}{l}54.26 \mathrm{a} \\
\pm 0.3\end{array}$ & $\begin{array}{l}54.12 \mathrm{a} \\
\pm 2.0\end{array}$ & $\begin{array}{c}54.48 \mathrm{a} \\
\pm 0.6\end{array}$ & $\begin{array}{l}53.69 \mathrm{~b} \\
\pm 1.0\end{array}$ & $\begin{array}{l}48.34 \mathrm{~d} \\
\pm 0.8\end{array}$ & 2.59 \\
\hline
\end{tabular}

Data are expressed as mean \pm SD. Values given represent means of three determinations. Means in the same row with different letters are significantly $(P \leq 0.05)$ different. LSD: least different significantly at $P \leq$ 0.05 according to Duncan's multiple range test. $*$ By difference. 
Table 2. Effect of different processing methods on mineral contents of cauliflower florets ( $\mathrm{mg} / 100 \mathrm{~g}$ dry weight basis).

\begin{tabular}{|c|c|c|c|c|c|c|c|c|}
\hline Treatment & K & $\mathrm{Ca}$ & $\mathrm{Fe}$ & $S$ & $\mathrm{Zn}$ & $\mathrm{Mg}$ & $P$ & $\mathrm{Mn}$ \\
\hline Raw & $3595 \mathrm{a}$ & $459.3 \mathrm{a}$ & $28.43 \mathrm{a}$ & $712.7 \mathrm{a}$ & $26.77 \mathrm{a}$ & $435.0 \mathrm{a}$ & $302.3 \mathrm{a}$ & $2.30 \mathrm{a}$ \\
\hline $\begin{array}{l}\text { Boiling } \\
4 \text { min. }\end{array}$ & $2702 \mathrm{e}$ & $422 \mathrm{~d}$ & $24.67 \mathrm{ed}$ & 682 ed & $22.4 \mathrm{~cd}$ & $404.7 \mathrm{e}$ & $272.7 \mathrm{e}$ & $1.993 \mathrm{~d}$ \\
\hline $\begin{array}{l}\text { Boiling } \\
6 \text { min. }\end{array}$ & $2670 \mathrm{f}$ & $413.7 \mathrm{e}$ & $24.1 \mathrm{e}$ & $678.3 \mathrm{~d}$ & $21.5 \mathrm{~d}$ & $390 \mathrm{f}$ & $263.7 \mathrm{f}$ & $1.95 \mathrm{~d}$ \\
\hline Steam & $3188 \mathrm{c}$ & $419.6 \mathrm{C}$ & $25.87 \mathrm{c}$ & $678.3 \mathrm{~b}$ & $23.5 \mathrm{bcd}$ & $414.3 \mathrm{~cd}$ & $288.3 c$ & $2.14 \mathrm{~b}$ \\
\hline $\begin{array}{l}\text { Microwave } \\
2 \text { Minute }\end{array}$ & $3236 \mathrm{~b}$ & $449 \mathrm{~b}$ & $26.13 b c$ & $702 b$ & 24.23 bc & $420.3 b c$ & $290.7 \mathrm{~b}$ & $2.27 \mathrm{a}$ \\
\hline $\begin{array}{c}\text { Microwave } \\
3 \text { Minute }\end{array}$ & $3242 b$ & $449.3 \mathrm{~b}$ & $26.83 \mathrm{~b}$ & $705.3 \mathrm{~b}$ & $25.67 \mathrm{ab}$ & $423 \mathrm{~b}$ & 294 b & $2.283 \mathrm{a}$ \\
\hline Frying & $3106 d$ & $432.7 \mathrm{c}$ & $25.0 \mathrm{~d}$ & $688 c$ & $23.2 \mathrm{bcd}$ & $410 \mathrm{de}$ & $281.7 \mathrm{~d}$ & $2.063 \mathrm{C}$ \\
\hline L.S.D & 10.86 & 7.205 & 0.7956 & 7.111 & 2.494 & 7.193 & 4.114 & 0.0563 \\
\hline
\end{tabular}

Data are expressed as mean \pm SD. Values given represent means of three determinations. Means in the same column with different letters are significantly $(P \leq 0.05)$ different. LSD: least different significantly at ( $P \leq 0.05)$ according to Duncan's multiple range test.

K : Potassium , Ca : Calcium, Fe: Iron , S: Sulphur, Zn: zink, Mg : Magnesium, P : Phosphorus, Mn : Manganese.

Table 3. Effect of different processing methods on the bioactive compound of Cauliflower florets ( $\mathrm{mg} / 100 \mathrm{~g}$ dry weight basis).

\begin{tabular}{|c|c|l|l|}
\hline Treatment & $\begin{array}{l}\text { Vitamin C }(\mathrm{mg} / \\
100 \mathrm{Gm} \mathrm{DW})\end{array}$ & $\begin{array}{l}\text { Total Phenolic } \\
\text { Content (mg gallic acid/11 } \\
\text { DW) }\end{array}$ & $\begin{array}{l}\text { Flavonoids mg } \\
\text { Catechin /100 DW) }\end{array}$ \\
\hline Raw & $63.40 \mathrm{a} \pm 4.7$ & $762.9 \mathrm{a} \pm 6.11$ & $236.3 \mathrm{a} \pm 7.18$ \\
\hline Boiling 4 min. & $26.83 \mathrm{~d} \pm 6.5$ & $454.9 \mathrm{~d} \pm 26.62$ & $144 \mathrm{c} \pm 24.35$ \\
\hline Boiling 6 min. & $22.23 \mathrm{e} \pm 2.5$ & $364.2 \mathrm{e} \pm 27.31$ & $117 \mathrm{~d} \pm 34.89$ \\
\hline Steam & $40.07 \mathrm{c} \pm 3.5$ & $542.2 \mathrm{c} \pm 17.29$ & $187.3 \mathrm{~b} \pm 12.53$ \\
\hline Microwave 2 Minute & $54.73 \mathrm{~b} \pm 1.6$ & $632.3 \mathrm{~b} \pm 3.81$ & $209.9 \mathrm{a} \pm 18.61$ \\
\hline Microwave 3 Minute & $46.97 \mathrm{~b} \pm 5.1$ & $619.9 \mathrm{~b} \pm 2.59$ & $202.8 \mathrm{a} \pm 18.87$ \\
\hline Frying & & $612.8 \mathrm{~b} \pm 35.63$ & $198 \mathrm{ab} \pm 13.31$ \\
\hline L.S.D & $43.40 \mathrm{~b} \pm 1.3$ & 18.95 & 19.60 \\
\hline
\end{tabular}

Data are expressed as mean \pm SD. Values given represent means of three determinations. Means in the same column with different letters are significantly $(P \leq 0.05)$ different. LSD: least different significantly at ( $P \leq 0.05)$ according to Duncan's multiple range test. 
Table 4. HPLC analysis of Phenolic acids ( $\mathrm{mg} / 100 \mathrm{~g}$ edible portion) of raw and processed Cauliflower

\begin{tabular}{|c|c|c|c|c|c|c|c|}
\hline $\begin{array}{l}\text { Phenolic } \\
\text { acids }\end{array}$ & Raw & $\begin{array}{l}\text { Boiling } 4 \\
\text { min. }\end{array}$ & $\begin{array}{l}\text { Boiling } 6 \\
\text { min. }\end{array}$ & Steam & $\begin{array}{l}\text { Microwave } \\
2 \text { min. }\end{array}$ & $\begin{array}{l}\text { Microwave } \\
3 \text { min. }\end{array}$ & Frying \\
\hline Gallic & 41.8 & 25.7 & 21.9 & 27.6 & 38.9 & 35.2 & 31.1 \\
\hline $\begin{array}{l}\text { 4- amino } \\
\text { benzoic }\end{array}$ & 1.6 & 0.4 & 0.3 & 0.6 & 1.2 & 0.9 & 0.7 \\
\hline $\begin{array}{l}\text { Stolleuro- } \\
\text { pein }\end{array}$ & 27.6 & 11.3 & 8.9 & 14.5 & 25.2 & 21.0 & 17.2 \\
\hline $\begin{array}{c}\text { Reverst- } \\
\text { erol }\end{array}$ & 32.3 & 11.6 & 8.1 & 14.9 & 28.8 & 23.9 & 17.8 \\
\hline Vanillic & 45.9 & 20.4 & 16.7 & 25.4 & 41.7 & 35.1 & 29.6 \\
\hline Caffein & 73.0 & 41.7 & 37.9 & 46.8 & 67.1 & 59.0 & 51.9 \\
\hline Catechol & 36.6 & 12.9 & 8.3 & 15.7 & 31.4 & 25.7 & 19.3 \\
\hline $\begin{array}{l}\text { Protocat- } \\
\text { choic }\end{array}$ & 32.5 & 11.6 & 7.8 & 14.6 & 27.3 & 21.3 & 16.9 \\
\hline Alpha-coumaric & 68.4 & 37.5 & 33.4 & 42.5 & 59.1 & 52.5 & 46.4 \\
\hline Coumarin & 21.2 & 3.1 & 1.9 & 5.1 & 16.8 & 10.7 & 6.5 \\
\hline $\begin{array}{c}\mathrm{P}- \\
\text { coumaric }\end{array}$ & 31.9 & 11.0 & 8.9 & 13.5 & 26.5 & 21.9 & 17.8 \\
\hline $\begin{array}{l}3-\mathrm{OH}- \\
\text { Tyrosol }\end{array}$ & 14.4 & 2.8 & 1.5 & 3.7 & 12.6 & 8.1 & 4.9 \\
\hline Total & 427.2 & 190.0 & 155.6 & 224.9 & 376.6 & 315.3 & 260.1 \\
\hline
\end{tabular}

Table 5. HPLC analysis of flavonoid contents ( $\mathrm{mg} / 100 \mathrm{~g}$ edible portion) of raw and processed Cauliflower.

\begin{tabular}{|c|c|c|c|c|c|c|c|}
\hline $\begin{array}{l}\text { Favonoid } \\
\text { Contents }\end{array}$ & Raw & $\begin{array}{c}\text { Boiling } 4 \\
\text { min. }\end{array}$ & $\begin{array}{c}\text { Boiling } 6 \\
\text { min. }\end{array}$ & Steam & $\begin{array}{l}\text { Microwave } \\
2 \text { min. }\end{array}$ & $\begin{array}{l}\text { Microwave } \\
3 \text { min. }\end{array}$ & Frying \\
\hline Naringin & 7.5 & 3.2 & 2.7 & 3.9 & 6.3 & 5.3 & 4.8 \\
\hline 7-hydroxy flay & 9.8 & 4.6 & 3.1 & 5.7 & 8.5 & 7.1 & 6.6 \\
\hline Apegenin & 14.6 & 9.2 & 7.7 & 10.1 & 13.4 & 12.9 & 11.8 \\
\hline Hespertin & 9.4 & 4.7 & 3.8 & 5.8 & 8.9 & 7.9 & 6.7 \\
\hline Rutin & 18.2 & 9.6 & 7.9 & 11.9 & 17.9 & 15.1 & 13.3 \\
\hline Hisperdin & 13.8 & 5.9 & 4.2 & 7.7 & 12.7 & 10.9 & 9.3 \\
\hline Rosmarinic & 4.1 & 1.8 & 0.9 & 2.3 & 3.8 & 2.7 & 2.9 \\
\hline Quercetrin & 9.2 & 4.8 & 3.3 & 5.9 & 8.6 & 7.4 & 6.8 \\
\hline Quercetin & 16.6 & 9.9 & 7.3 & 11.1 & 15.7 & 13.8 & 12.1 \\
\hline Naringinin & 15.3 & 8.7 & 7.1 & 10.5 & 14.5 & 12.9 & 11.9 \\
\hline $\begin{array}{l}\text { Kaempfe- } \\
\text { rol }\end{array}$ & 13.9 & 7.3 & 5.7 & 8.5 & 12.8 & 10.1 & 9.2 \\
\hline Total & 132.4 & 57.3 & 53.7 & 83.4 & 123.1 & 106.1 & 95.4 \\
\hline
\end{tabular}


Table 6. Total Carotenoids and antioxidant activity of raw and processed Cauliflower.

\begin{tabular}{|c|c|c|c|c|c|c|c|}
\hline Parameter & Raw & $\begin{array}{c}\text { Boiling 4 } \\
\text { min. }\end{array}$ & $\begin{array}{c}\text { Boiling 6 } \\
\text { min. }\end{array}$ & Steam & $\begin{array}{c}\text { Micro- } \\
\text { wave } \\
2 \text { min. }\end{array}$ & $\begin{array}{c}\text { Micro- } \\
\text { Wave } \\
3 \text { min. }\end{array}$ & Frying \\
\hline $\begin{array}{c}\text { Total Carotenoid } \\
\text { Content (Mg/100g } \\
\text { Dry weight) }\end{array}$ & 132.11 & 61.74 & 51.90 & 108.27 & 119.48 & 114.67 & 55.30 \\
\hline antioxidant activity \% & 59.22 & 28.55 & 25.24 & 42.49 & 52.21 & 50.83 & 48.72 \\
\hline
\end{tabular}

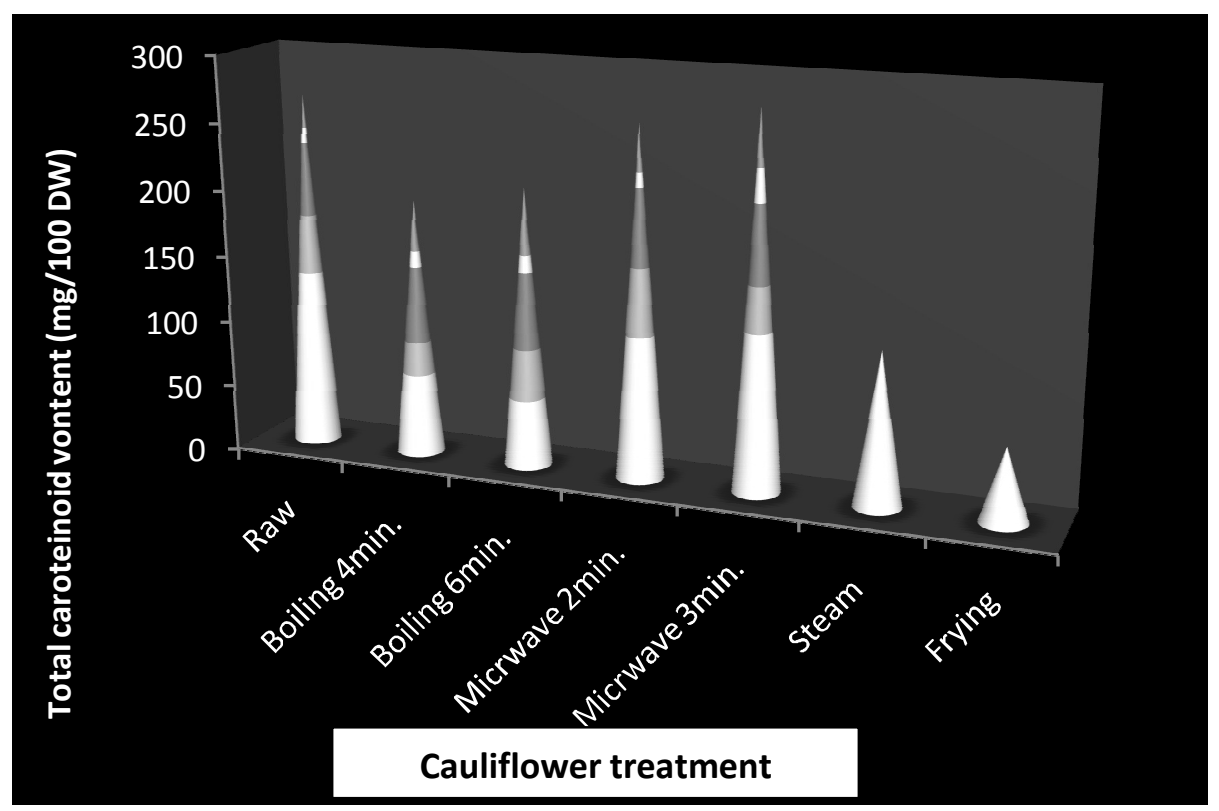

Figure 1. Total carotenoids of raw and processed Cauliflower

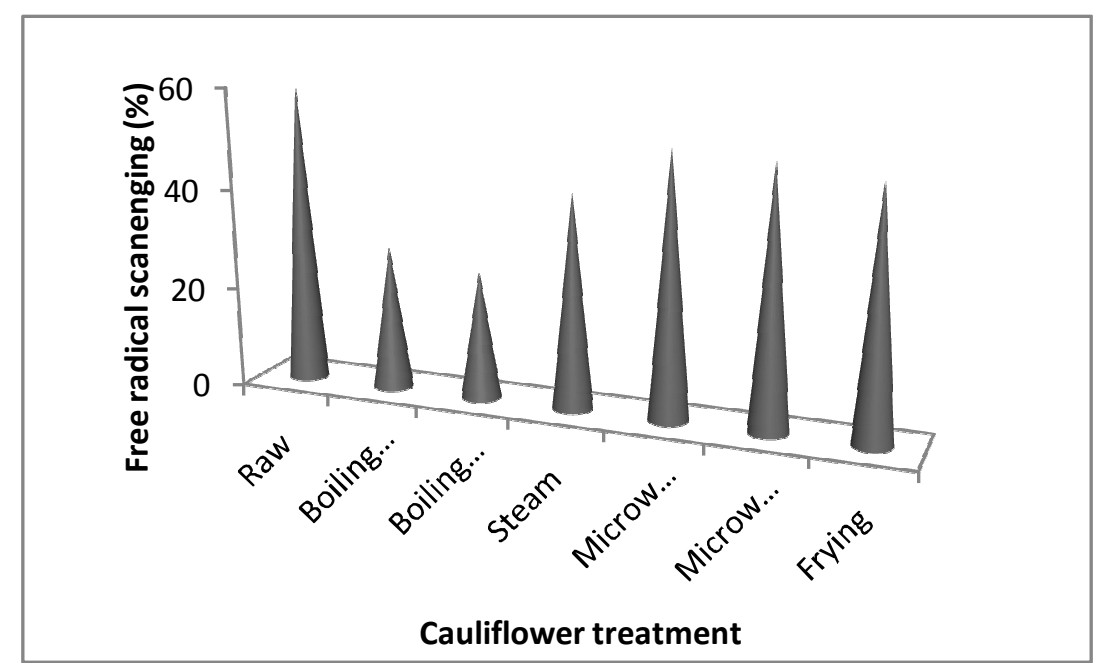

Figure 2. Antioxidant activity of raw and processed Cauliflower 


\section{REFERENCES}

1. Anwar, F., Kalsoom, U., Sultana, B., Mushtaq, M., Mehmood, T., and Arshad, H. A. 2013. Effect of drying method and extraction solvent on the total phenolics and antioxidant activity of cauliflower (Brassica oleracea L.) extracts .International Food Research Journal 20(2):653-659.

2. A.O.A.C. 2005. Official Methods of the Analysis of AOAC. International18th Edition, Published by AOAC International. Maryland 20877- 2417. USA.

3. Chun O.K., Smith N., Sakagawa A. and Lee C.Y. 2004. Antioxidant properties of raw and processed cabbages International Journal of Food Science and Nutrition, 55: 191-199.

4. .De sa, M. C. and Rodriguez, D.B. 2004. Optimization of HPLC quantification of carotenoids in cooked green vegtables. Comparison of analytical data. J. Food Composition and Analysis, 17: 37-51.

5. Francisco, M., Velasco, P., Moreno, D. A. Garc'ia-Viguera, C. and Cartea, M. E. 2010. "Cooking methods of Brassica rapa affect the preservation of glucosinolates, phenolics and vitamin C," Food Research International, vol. 43, no. 5, pp. 1455-1463.

6. Gernah, D.I., Ega, B.M., and Umoh, U.E. 2012."Effect of boiling time on the quality of "Zogale": a snack food produced from peanut (Arachis hypogea) cake and boiled Moringa oleifera leaves. African Journal of Food Science, vol. 6, no. 10 , pp. 287-293.

7. Goupy, P., Hugues, M., Boivin, P. and Amiot, M. 1999. Antioxidant composition and activity of barley (Hordeum vulgare) and malt extracts and of isolated phenolic compounds. J. Sci. Food and Agric., 79: 1625-1634.

8. Ismail, A. and W.Y. Lee. 2004. Influence of cooking practice on antioxidant properties and phenoliccontent of selected vegetables. Asia Pacific J. Clinical Nutrition, 13(Suppl.), S162

9. Lin L.Z., Harnly J.M. 2010. Phenolic component profiles of mustard greens, yu choy and 15 other Brassica vegetables, Journal of Agricultural and Food Chemistry,58: 6850-6857.

10. Puupponen-Pimia, R., Hakkinen, S. T. Aarni, H. 2003. "Blanching and long-term freezing affect various bioactive compounds of vegetables in different ways," Journal of the Science of Food and Agriculture, vol. 83, no. 14, pp. 1389-1402.

11. Ramesh, B. and Satakopan, V. N. 2010. Invitro antioxidant activities of Ocimum species: Ocimum basilicum and Ocimum sanctum. Journal of Cell and Tissue Culture Research , 10 (1): 2145-2150. 
12. Sangeeta S. and Charu L. M. 2013. Effect of steaming, boiling and microwave cooking on the total phenolics, flavonoids and antioxidant properties of different vegetables of Assam, India. International Journal of Food and Nutritional Sciences, 2(3): 47-53.

13. Savinder K. M. and Namita K. 2013. Health promoting effects of phytochemicals from Brassicaceae: A Review. Indian J. Pharm. Biol. Res Vol. 1(3), ISSN:23209267.

14. SAS, Statistical Analysis System, 1986. SAS User's Guide: Statistics, Version 5ed. SAS Inst, Inc., Cary, NC, USA.

15. Shams El-Din, M.H.A., Madiha M. A:, Makhlouf S. K. and Ola S.S. 2013. Effect of some cooking methods on natural antioxidants and their activities in Some Brassica vegetables. World Applied Sciences Journal 26 (6): 697-703.

16. Slinkard S. and Singleton, V.L. 1977. Total phenol analysis, automation and comparison with manual methods Am J Enology and Viticul, 28: 49-55.

17. Souci, S.W., Fachmann, W. and Kraut, H. 1994. Food Composition and Nutrition Tables, CRC Press, Medpharm Scientific Publishers New York, NY, USA, 5th edition

18. Sun, L., Bai, X. and Zhuang, Y. 2012. "Effect of different cooking methods on total phenolic contents and antioxidant activities of four Boletus mushrooms," Journal of Food Science and Technology.

19. Yuan, G.F., Sun, B., Yuan, J. and Wang, Q.M. 2009. "Effects of different cooking methods on health-promoting compounds of broccoli," Journal of Zhejiang University B, vol.10, no. 8, pp. 580-588.

20. Zhang, J.J., R. Ji, Y.-Q. Hu, J.-C. Chen, and X.-Q. Ye. 2011. "Effect of three cooking methods on nutrient components and antioxidant capacities of bamboo shoot (Phyllostachys praecox C.D Chu et C.S. Chao)," Journal of Zhejiang University B, vol. 12, no 9, pp. 752-759. 


\title{
تأثير طرق تصنيع الغذاء على المركبات النشطه حيويا فى القرنبيط
}

\author{
عفاف محمد علي \\ قسم بحوث تصنيع الحاصلات البستانيه- معرد بحوث تكنولوجبا الاغذيه - مركز البحوث الزراعيه- جيزه- مصر
}

تعتبر العائله الصليبيه غنيه جدا بالمركبات النشطه حيويا متل المركبات الفينوليه وفيتامين ج . اجريت هذه الدر اسه بغرض تقييم تأثثر طرق التصنيع المختلفه (كالسلق بالماء لمده عق، بات بق و السلق

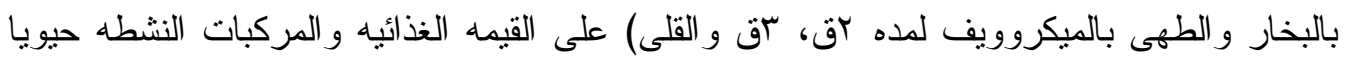

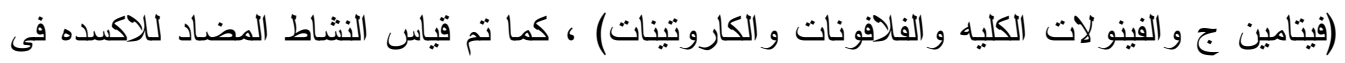
القرنبيط باستخدام ماده داى فينيل بيكريل هيدر ازيل . أوضحت النتائج ان طريقه السلق بالماء لها اكبر تأيبر سلبى على الميلى المكونات الغذائيه ، كما تسبيت

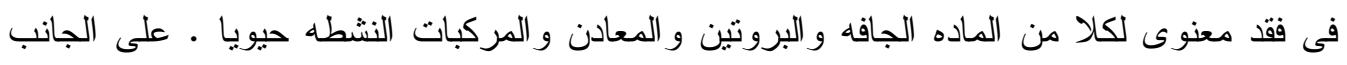
الاخر أظهر الميكروويف أقل فقد يليه القلى ثم الطهى بالبخار . مستخلص الميثانول للقرنبيط الطازج

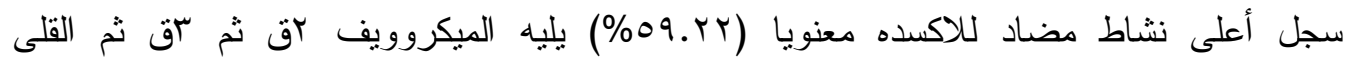

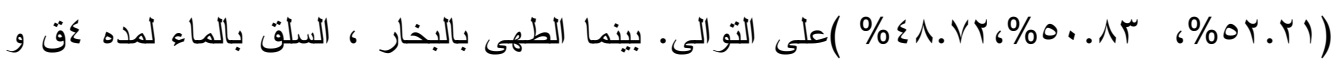

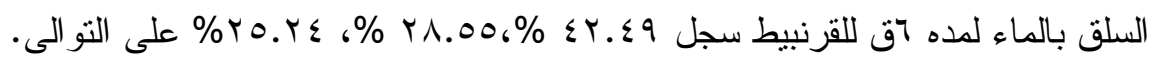

